\title{
Moving carbon between spheres, the potential oxalate-carbonate pathway of Brosimum alicastrum Sw.; Moraceae
}

\author{
Mike C. Rowley • Héctor Estrada-Medina • \\ Magnolia Tzec-Gamboa • Aviram Rozin • \\ Guillaume Cailleau • Eric P. Verrecchia • Iain Green
}

Received: 31 August 2016/Accepted: 26 October 2016/Published online: 16 December 2016

(C) The Author(s) 2016. This article is published with open access at Springerlink.com

\begin{abstract}
Aims The Oxalate-Carbonate Pathway (OCP) is a biogeochemical process that transfers atmospheric $\mathrm{CO}_{2}$ into the geologic reservoir as $\mathrm{CaCO}_{3}$; however, until now all investigations on this process have focused on species with limited food benefits. This study evaluates
\end{abstract}

Responsible Editor: Hans Lambers.

Study locations Merida, Yucatán Peninsula, Mexico: Oxtapacab $\left(20.77111^{\circ} \mathrm{N} / 89.50417^{\circ} \mathrm{W}\right)$, San Jose Tzal $\left(20.824167^{\circ} \mathrm{N} /\right.$ $\left.89.66111^{\circ} \mathrm{W}\right)$, Tzucacab $\left(20.07083^{\circ} \mathrm{N} / 89.05055^{\circ} \mathrm{W}\right)$ and Haiti: Anse-à-Pitres $\left(18.04306^{\circ} \mathrm{N} / 71.75833^{\circ} \mathrm{W}\right)$, Anse-Rouge $\left(19.63333^{\circ} \mathrm{N} / 73.05000^{\circ} \mathrm{W}\right)$.

\section{Highlights}

1) Calcium oxalate identified in all analysed Brosimum alicastrum.

2) $\mathrm{CaOx}$ crystals probably help its younger form augment incident

UV-radiation in light-limited environments.

3) Ma Rouge, a Haitian sampling site, demonstrated signs of early onset oxalotrophy.

4) Root-like secondary carbonate deposits were discovered in Mexico.

5) Evidence suggests that Brosimum alicastrum is oxalogenic and that oxalogenesis can occur in calcareous environments.

This research's sampling was funded by Bournemouth University, Biomimicry Europa, and Sadhana Forest.

Electronic supplementary material The online version of this article (doi:10.1007/s11104-016-3135-3) contains supplementary material, which is available to authorized users.

M. C. Rowley · G. Cailleau · E. P. Verrecchia

Université de Lausanne, Faculté des Géosciences et de

l'Environnement (GSE), Institut des Dynamiques de la Surface

Terrestre (IDYST), Lausanne, Switzerland a potential OCP associated with Brosimum alicastrum, a Neotropical species with agroforestry potential ( $c a$. 70-200 kg-nuts $\mathrm{yr}^{-1}$ ), in the calcareous soils of Haiti and Mexico.

Methods / results Enzymatic analysis demonstrated significant concentrations of calcium oxalate $(5.97 \%$ D.W.) were associated with $B$. alicastrum tissue in all sample sites. The presence of oxalotrophism was also confirmed with microbiological analyses in both countries. High concentrations of total calcium $\left(>7 \mathrm{~g} \mathrm{~kg}^{-1}\right)$ and lithogenic carbonate obscured the localised alkalinisation and identification of secondary carbonate associated with the OCP at most sample sites, except Ma Rouge, Haiti. Soils adjacent to subjects in Ma Rouge demonstrated an increase in $\mathrm{pH}(0.63)$ and $\mathrm{CaCO}_{3}$ concentration $(5.9 \%)$ that, when coupled with root-like secondary carbonate deposits in Mexico, implies that the OCP does also occur in calcareous soils.

Conclusions Therefore this study confirms that the OCP also occurs in calcareous soils, adjacent to B. alicastrum, and could play a fundamental and un-accounted role in the global calcium-carbon coupled cycle.

Keywords Oxalate-Carbonate Pathway (OCP) . Brosimum alicastrum $\cdot$ Calcium oxalate $\cdot$ Carboncalcium cycle $\cdot$ Oxalotrophic bacteria

\section{Introduction}

Soils play a major role in the cycling of carbon (C) and understanding the processes that regulate $\mathrm{C}$ migration 
from one reservoir to the next is of globally recognised significance. The Oxalate-Carbonate Pathway (OCP; Fig. 1) is a biogeochemical cycle that results in the transfer of atmospheric carbon dioxide $\left(\mathrm{CO}_{2}{ }^{\mathrm{Atm}}\right)$ into the geologic $\mathrm{C}$ reservoir within soils, as calcium carbonate $\left(\mathrm{CaCO}_{3}\right)$. The process probably plays an important role in the regulation of $\mathrm{CO}_{2}{ }^{\mathrm{Atm}}$ within the global C cycle (Cailleau et al. 2005; Cailleau et al. 2014) when the source of calcium $(\mathrm{Ca})$ is provided by silicate rocks. OCP has several key components, involving; calcium oxalate $\left(\mathrm{CaOx} ; \mathrm{CaC}_{2} \mathrm{O}_{4} \cdot n \mathrm{H}_{2} \mathrm{O}\right)$ producing plants, fungi, phytophagous invertebrates, and oxalotrophic bacteria (Cailleau et al. 2004, 2011; Cailleau et al. 2014; Garvie 2006). The first stage commences when $\mathrm{CO}_{2}{ }^{\mathrm{Atm}}$ is fixed by RuBisCo during photosynthesis, forming biomass and oxalic acid $\left(\mathrm{H}_{2} \mathrm{C}_{2} \mathrm{O}_{4}\right.$; Fig 2). Oxalic acid can then be converted into insoluble $\mathrm{CaOx}$ crystals $\left(\mathrm{K}_{\mathrm{sp}} \approx 10^{-8.5}\right.$; Certini et al. 2000; Monje and Baran 2002; Palak et al. 2012) by plants within specialised cells called crystal idioblasts (Faheed et al. 2013; Franceschi and Nakata 2005; Nakata 2002, 2003). These $\mathrm{CaOx}$ crystals are subsequently released during herbivory and decomposition, creating a $\mathrm{CaOx}$ pool adjacent to the producing species, in its rhizosphere (Cailleau et al. 2011; Jayasuriya 1955), stomachs of endopedonic species (Bassalik 1913), or within phytoabrasions (Cailleau et al. 2004; Verrecchia et al. 2006). Consequently, this pool of $\mathrm{CaOx}$ can then be catabolised by bacteria, labelled oxalotrophic through either the common glycolate- (Bravo et al. 2013; Chandra and Shethna 1977; Tamer and Aragno 1980) or less common serine-pathway (Sahin 2003), precipitating $\mathrm{C}$ as $\mathrm{CaCO}_{3}$ and creating a distinct local alkalinisation of acidic soils (Cromack et al. 1977; Fig. 3). Therefore, an active OCP has the ability to biominerally transfer $\mathrm{CO}_{2}{ }^{\mathrm{Atm}}$ within the geologic reserve.

Although there have been numerous studies on the OCP, analysis has typically focused on tree species in

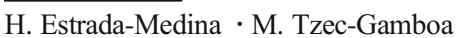

Universidad Autónoma de Yucatán, Campus de Ciencias

Biológicas y Agropecuarias, Mérida, Mexico

A. Rozin

Sadhana Forest, Auroville, Tamil Nadu, India

M. C. Rowley $(\bowtie) \cdot$ I. Green

Bournemouth University, Faculty of Science and Technology,

Poole, UK

e-mail: mike.rowley@unil.ch

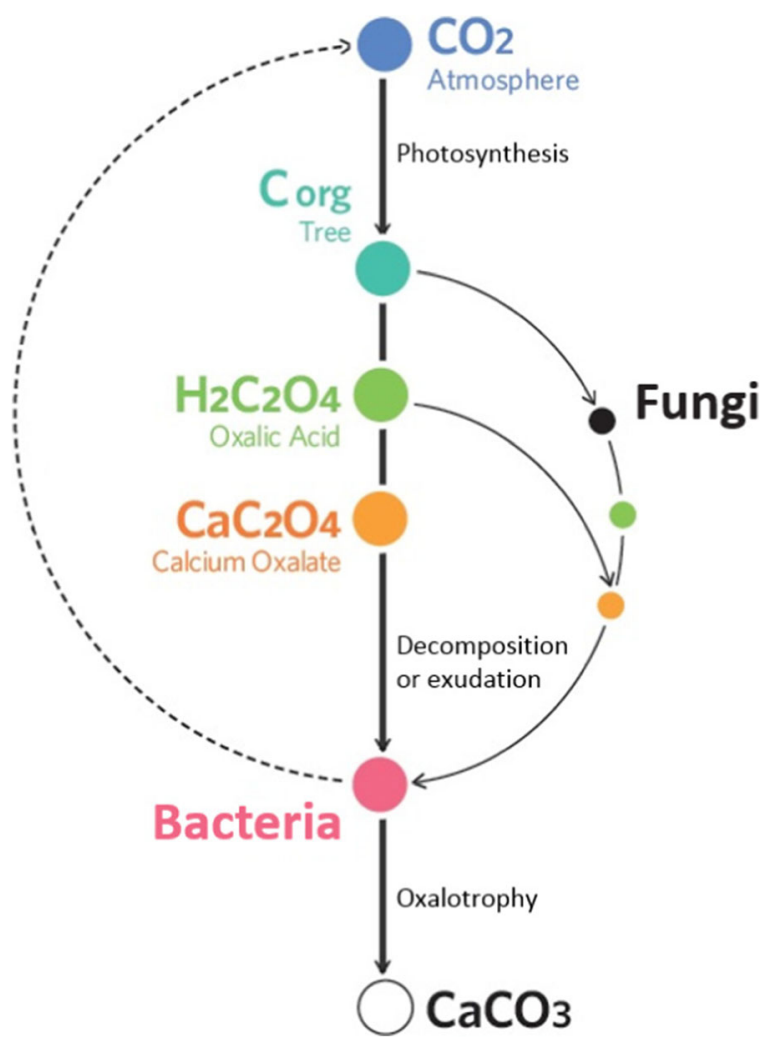

Fig. 1 A simplified model of the Oxalate-Carbonate Pathway (OCP), a process that transfers carbon dioxide from atmosphere to secondary calcium carbonate. As described by Cailleau et al. (2014), the process commences when a calcium oxalate producing species (Tree) organically sequesters carbon during photosynthesis (Corg), converting it into oxalic acid and then calcium oxalate. Once released from organic material during decomposition or as exudes, calcium oxalate is subsequently catabolised by oxalotrophic bacteria (Bact.), converting one mol as carbonate and releasing another as respired carbon dioxide. Fungi also assist in the process by either breaking down oxalic rich matter and depositing calcium oxalate for catabolism by bacteria, or by fungal oxalotrophy

$$
\begin{aligned}
& \text { 1.) } \mathrm{C}_{6} \mathrm{H}_{12} \mathrm{O}_{6}+\mathrm{O}_{2} \Rightarrow 2 \mathrm{C}_{3} \mathrm{H}_{4} \mathrm{O}_{3}+2 \mathrm{H}_{2} \mathrm{O} \\
& \text { 2.) } 2 \mathrm{C}_{3} \mathrm{H}_{4} \mathrm{O}_{3}+2 \mathrm{CO}_{2} \Rightarrow 2 \mathrm{C}_{4} \mathrm{H}_{4} \mathrm{O}_{5}
\end{aligned}
$$

3.) $2 \mathrm{C}_{4} \mathrm{H}_{4} \mathrm{O}_{5}+2 \mathrm{H}_{2} \mathrm{O} \Rightarrow 2 \mathrm{H}_{2} \mathrm{C}_{2} \mathrm{O}_{4}+2 \mathrm{H}_{4} \mathrm{C}_{2} \mathrm{O}_{2}$

$$
\text { 4.) } 2 \mathrm{Ca}^{2+}+2 \mathrm{H}_{2} \mathrm{C}_{2} \mathrm{O}_{4}+\mathrm{O}_{2} \Rightarrow 2 \mathrm{CaC}_{2} \mathrm{O}_{4} \cdot \mathrm{H}_{2} \mathrm{O}
$$

Fig. 2 Oxalic acid production and subsequent precipitation of calcium oxalate from glucose. 1.) Glucose is first oxidated to form pyruvate. 2.) Then pyruvate is carboxylated to produce oxaloacetate. 3.) The subsequent hydrolysis of oxaloacetate forms oxalate and acetate. 4.) Where $\mathrm{Ca}^{2+}$ can then react with oxalic acid to form calcium oxalate as either mono- or di-hydrate crystals (Verrecchia 1990; Verrecchia et al. 2006) 


$$
\begin{aligned}
& 1000 \mathrm{CaC}_{2} \mathrm{O}_{4} \cdot n \mathrm{H}_{2} \mathrm{O}+372 \mathrm{O}_{2}+32 \mathrm{NH}_{4}^{+} \\
\Rightarrow & 32 \mathrm{C}_{4} \mathrm{H}_{8} \mathrm{O}_{2} \mathrm{~N}_{\text {Biomass }}^{+}+936 \mathrm{CaCO}_{3}+64 \mathrm{Ca}^{+}\left(\mathrm{OH}_{2}\right)_{\mathrm{aq}} \cdots \\
& \ldots+(1000 .(n-2)+1872) \mathrm{H}_{2} \mathrm{O}+936 \mathrm{CO}_{2}
\end{aligned}
$$

Fig. 3 Oxalotrophic catabolism of calcium oxalate by bacteria (in Verrecchia et al. 2006, from Harder et al. 1974)

acidic soil environments. At current, investigations have confirmed 24 species are associated with active OCPs (Braissant et al. 2002; Cailleau et al. 2004; Cailleau et al. 2014; Ferro 2012; Garvie 2003, 2006; Monje and Baran 2002), typically utilising the emblematic localised alkalinisation of acidic soils as a geochemical proxy for oxalogenesis. The most heavily investigated OCP is associated with Milicia excelsa Welw. (Moraceae) in ferralitic soils of Africa (Aragno et al. 2010; Braissant et al. 2004; Braissant et al. 2002; Cailleau et al. 2005; Cailleau et al. 2004; Martin et al. 2012). For which, Cailleau et al. (2011) demonstrated a potential sequestration of $c a$. $1 \mathrm{t} \mathrm{C}$ as $\mathrm{CaCO}_{3}$ throughout a model individual's lifetime. Later work identified a further two species within the Moraceae family (Cailleau et al. 2014), associated with an OCP, while earlier work has demonstrated $\mathrm{CaOx}$ production in several other species within the family (Wu and Kuo Huang 1997), including the food-producing genus Brosimum (Scholz et al. 2007). However, most studies on the OCP have focused on species without agroforestry potential and there has currently been no investigations into a potential OCP associated with the Moraceae genus Brosimum.

Brosimum alicastrum Swartz, Moraceae (B. alicastrum) is a large Neotropical, ever-green, canopy-emergent tree species utilised in Central America for agroforestry purposes and conservation marketing operations. It is common throughout the dry and wet semi-evergreen forests of the Caribbean, Central America, and Northern-South America (Ortiz et al. 1995; Yates and Ramirez-Sosa 2004). The species has a height range of around $20-40 \mathrm{~m}$, increasing with precipitation, and a common Diameter at Breast Height (DBH) of 1-1.5 m, increasing North-south (Peters 1983, 1989). It is a species shown to be drought resistant (Brewer et al. 2003; Querejeta et al. 2006), growing well in Leptosols of different biomes, while producing nutritious nuts (Peters and Pardo-tejeda 1982). These natural products can be processed to form a range of foods, medicines and excellent fodder for almost all large gregarious mammals, (Gillespie et al. 2004; Ricogray et al. 1991). The species starts seed production after reaching sexual maturity (i.e. 5-7-yr) and, thereafter, an individual can produce around 70$200 \mathrm{~kg}$-seeds $\mathrm{yr}^{-1}( \pm 30 \mathrm{~kg})$ throughout its 150 200-yr life cycle (Gillespie et al. 2004; Ortiz et al. 1995; Peters 1983, 1989). Furthermore, recent work by Woda and Martinez (2013) has shown that $B$. alicastrum's seeds have an established, economic harvest return of US $\$ 650$ ha $\mathrm{yr}^{-1}$ in Honduras,

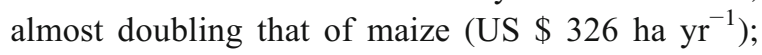
thus, highlighting the potential of $B$. alicastrum as an effective agroforestry crop.

If $B$. alicastrum was found to be in association with an active OCP, it would represent an ideal agroforestry crop with biomineral $\mathrm{C}$ fixation capabilities. However, currently the OCP has only been identified in acidic soils, free from inherited carbonate (Cailleau et al. 2014), unlike the predominate habitat of B. alicastrum (Peters and Pardo-tejeda 1982). The presence of carbonate in calcareous soils increases the complexity of identifying an OCP (Cailleau et al. 2014), but shouldn't prevent its identification through the analysis of the process' constituents and geochemical proxies. Therefore, the aim of this work is to ascertain if $B$. alicastrum is associated with an active oxalate-carbonate pathway in the calcareous soils of Haiti and Mexico, via the following questions:

1) Does $B$. alicastrum produce $\mathrm{CaOx}$, and if so, is there geochemical evidence of an active OCP adjacent to the species in calcareous soils?

2) Are there oxalotrophic bacterial communities in calcareous soils adjacent to subject $B$. alicastrum in both Haiti and Mexico?

3) What is the $\mathrm{C}$ fixation potential of a model $B$. alicastrum agroforestry system in calcareous soils?

\section{Materials \& methods}

Site settings

Calcareous sample sites were selected with notable environmental and biogeographical similarities in Anse-à- 
Pitres (A, B - Banane, C - Bony, D - Ma Rouge) and Anse Rouge (E), Haiti and, the Yucatán Peninsula (F Tzucacab, G - Oxtapacab, H - San Jose Tzal), Mexico (Fig. 4). The Yucatán sites sit atop a partially emergent carbonate platform of low-lying, Tertiary limestone karst and were typically characterised as either Calcic or Calcaric Leptosols or Cambisols in Oxtapacab and San Joze Tazal, or Luvisols in Tzucacab (Ramos 1975; Shang and Tiessen 2003; WRB 2015) that receive an annual rainfall of approximately $1,100 \mathrm{~mm} \mathrm{yr}^{-1}$ (Giddings and Soto 2003). Mexico provided mature trees in contrast with Haiti, where only recent plantations were available for sampling. Anse-à-Pitres and Anse Rouge also sit atop Tertiary limestone karst, with thin eroded soils that were predominately classified as Calcaric or Calcic Cambisols, although several sites in Ma Rouge presented a non-calcareous nature (just below classification of Calcaric $\leq 2 \% \mathrm{CaCO}_{3}$; WRB 2015). Accurate climatic data on the two regions is sparse, but both regions are subject to an annual hurricane season of fluctuating strength (Whigham and Lynch 1998; Whigham et al. 2003), which just preceded sampling for this investigation (2013).

\section{Sampling}

A sample of 50 subject $B$. alicastrum of varying size and maturity were selected from both study countries (20 Mexican, 30 Haitian) using stratified-random techniques. Two samples were taken from each subject, an experimental sample from adjacent to the subject and a control sample, exogenous of the subject's zone of lateral edaphic influence (3.5-25 $\mathrm{m}$ depending on subject height). To analyse the bulk differences between adjacent and control sites, all soil profiles were taken to their shallow bedrock $(10-40 \mathrm{~cm})$ and bulked.

Samples of B. alicastrum tissue were taken from each subject for biogeochemical analyses. 3 Foliar and 3 branch samples were taken from the lowest branches of each subject, mid-branch, ensuring uniformity

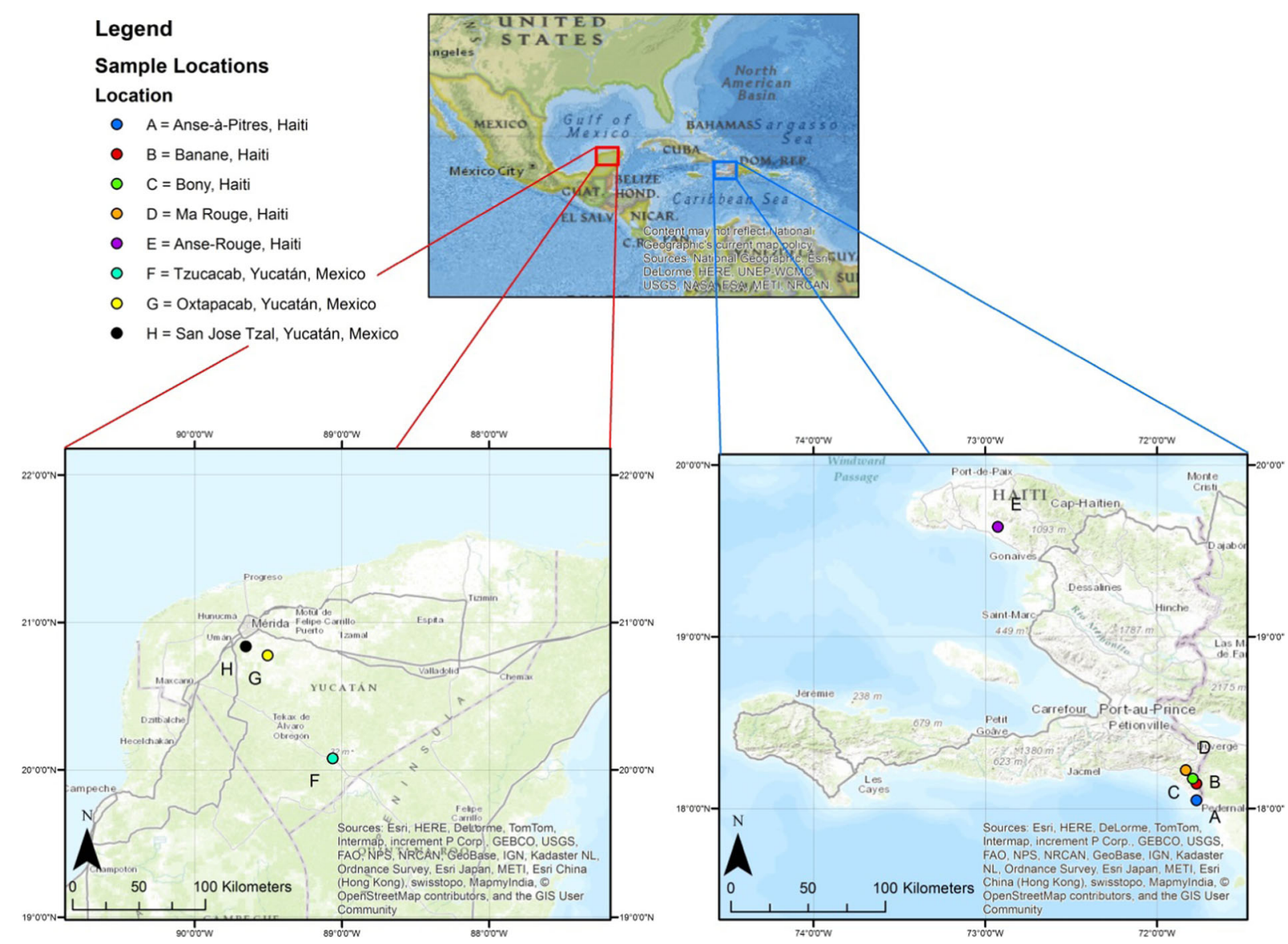

Fig. 4 Sample sites in Haiti and Mexico (Esri 2014) 
amongst samples in both countries. Root and bark samples were only taken from Mexican subjects to restrict the damage to the younger trees in Haiti. Subject locations were recorded using GPS systems (Opteka GPS \& Garmin GPS 76) and measurements of DBH, soil sample depth, and height, were obtained using $30 \mathrm{~m}$ tape and, where necessary, in conjunction with a clinometer (Sokkia No. 8047).

\section{Sample preparation}

All soil and plant samples, except those for bacterial analyses, were air-dried in the field to prevent decomposition and decay, and then transported to Bournemouth for laboratory analyses via courier. Bournemouth samples were autoclaved (Astell Swiftlock Securetouch $+; 121{ }^{\circ} \mathrm{C}$ for 30 mins) on arrival as part of the plant health licence (Food, Environment and Rural Affairs) for importing foreign soils and plant material into the UK. Soil samples were then sieved to fine earth fraction $(<2 \mathrm{~mm})$ for chemical analysis, while plant samples were homogenised using a rotor mill and stainless steel-bore mill kit (Retsch MM200). Field-moist samples from each study site, except Anse Rouge, were sent urgently to a laboratory in the Yucatan for bacterial analysis and stored at $4{ }^{\circ} \mathrm{C}$ prior to examination. Live samples from Haiti were delayed in Mexican customs for a month, but were also held at $4{ }^{\circ} \mathrm{C}$.

\section{Calcium oxalate analysis}

\section{Microscopy}

The presence of $\mathrm{CaOx}$ in $B$. alicastrum tissue was first identified using optical and Scanning Electron Microscopy (SEM). Samples were prepared for optical microscopy using techniques adapted from Ilarslan et al. (2001). Various tissues from both countries were submerged in Carnoy Fluid (3:1 ethyl alcohol: acetic acid) and left in Petri dishes for $24 \mathrm{~h}$, then re-submerged in ethyl alcohol for $1.5 \mathrm{~h}$. Samples were then coated in $2.5 \%$ sodium hypochlorite and rested for $4 \mathrm{~h}$ before mounting with glycerine-gelatine. Slides were observed with an Olympus BX51 compound microscope, using both dark and light field microscopy, and images were captured with an Olympus DP70 Digital Microscope Camera (Olympus Inc.).

SEM and Energy Dispersive X-ray Spectroscopic (SEM/EDS) techniques adapted from Garvie (2003) were used to image and detect the composition of observed crystals. Homogenised plant tissue was applied to alloy stubs using adhesive stickers and AuPd sputter coated (B-7341 Agar Auto Sputter Coater) for 40-60 s. Samples were subsequently analysed in high vacuum using a Jeol JSM-6010 Plus/LV SEM, with an INCA Xsight 8129 EDS system (ETAS Inc.), and InTouchScreen software. All EDS readings represent a percentage of the analysed substance's atomic weight and were recorded in K-band. Furthermore, surficial measurements are considered semi-quantitative as these measurements are applied to 3-dimensional objects.

\section{Enzymatic oxalate analysis}

Calcium oxalate concentrations of each $B$. alicastrum sample were quantified using a commercial Enzymatic Oxalate Kit (EOK; Trinity Biotech Plc; Cailleau et al. 2014; Certini et al. 2000). The EOK functions through the oxidation of oxalate by the enzyme (oxalate oxidase) into $\mathrm{CO}_{2}$ and hydrogen peroxide, which is subsequently oxidized by peroxidase, 3-methyl-2-benzthiazlinone hydrazine (MBTH) and 3-dimethylamino benzoic acid (DMAB) into an indamine dye with a maximum absorbance of $590 \mathrm{~nm}$. Sub-samples of $0.1 \mathrm{~g}$ were taken from each plant tissue sample and placed into $30 \mathrm{~mL}$ tubes, combined with $5 \mathrm{~mL} 1 \mathrm{M}$ hydrochloric acid $(\mathrm{HCl})$ extractant and shaken for $16 \mathrm{~h}$ at 150 revs min $^{-1}$ (Bibby Stuart Orbital Shaker SO1). The extractants were then centrifuged at 3,000 revs $\mathrm{min}^{-1}$ for $5 \mathrm{mins}$ (Heraeus Instruments Megafuge 1.0) and $1 \mathrm{~mL}$ supernatant transferred into new $30 \mathrm{~mL}$ tubes. This was subsequently combined with $4 \mathrm{~mL}$ Ultra-Pure $\mathrm{H}_{2} \mathrm{O}$ (Millipore ${ }^{\mathrm{TM}}$; $18.2 \mathrm{~m} \Omega$ at $25^{\circ} \mathrm{C}$ ) and $0.4 \mathrm{~mL} 2 \mathrm{M}$ sodium hydroxide $(\mathrm{NaOH})$ for $\mathrm{pH}$ correction (pH 5-7) and, thereafter, the manufacturer's instructions were followed. Absorbance was then measured at $590 \mathrm{~nm}$ using a Carey $50 \mathrm{UV} / \mathrm{vis}$ spectrophotometer (Varian Inc.) after $20 \mathrm{~min}$ had elapsed to allow full colour development. Certain soil samples were also measured with the same techniques, adjusting the extraction procedure for the lower concentrations of oxalate. The kits reported the oxalate concentration in $\mathrm{mg} \mathrm{kg}^{-1}$ which was then adjusted by multiplying the concentrations by the difference in M.W. (1.66) between whewellite $(\mathrm{CaOx}$ monohydrate; $\mathrm{CaC}_{2} \mathrm{O}_{4} \cdot \mathrm{H}_{2} \mathrm{O}$ M.W.: $\left.142.112 \mathrm{~g} \mathrm{M}^{-1}\right)$ and oxalate $\left(\mathrm{C}_{2} \mathrm{O}_{4}{ }^{-2}\right.$ M.W.: $\left.88.019 \mathrm{~g} \mathrm{M}^{-1}\right)$ to give $\mathrm{CaOx}$ monohydrate concentrations of each sample. 
Total carbon analysis

Total $\mathrm{C}$ was ascertained using dry combustion techniques adapted from Wright and Bailey (2001), analysing the tissue of randomly selected B. alicastrum subjects from each sampling location. Briefly, triplicates of 1-2 mg of homogenised sample were placed into a tin capsule (Barry and Pinkard 2013; Schutz et al. 2009) and combusted at $1,600{ }^{\circ} \mathrm{C}$ in a thermal elemental analyser (Thermo Finnegan FlashEA 1112), standardising peak integration by combusting 2.5 -Bis (5-tert-butyl-benzoxazol-2-yl) thiophene (BBOT).

Analysis of edaphic variables associated with the OCP

\section{Loss on ignition}

Organic matter content (\% OM) of each soil sample was calculated through loss on ignition (Cailleau et al. 2014). $1 \mathrm{~g}$ of oven dried $\left(105{ }^{\circ} \mathrm{C}\right.$; Memmert UN 55) soil was furnaced (Carbolite model OAF $11 / 1$ ) at $450{ }^{\circ} \mathrm{C}$ for $12 \mathrm{~h}$ and the percentage mass loss on ignition calculated.

\section{Soil pH}

$\mathrm{pH}_{\mathrm{H} 2 \mathrm{O}}$ was measured using techniques adapted from Cailleau et al. (2005). $4 \mathrm{~g}$ of soil was combined with $10 \mathrm{~mL}$ of distilled water $\left({ }_{d} \mathrm{H}_{2} \mathrm{O}\right)$, reposed for $16 \mathrm{~h}$ and measured in triplicate with a $\mathrm{pH}$ meter (Hach H135 Mini-lab Pro).

\section{ICP-OES}

The elemental composition of all soil samples was ascertained using a Vista-Pro CCD Simultaneous Inductively Coupled Plasma-Optical Emission Spectrometer (ICP-OES; Varian inc.) and different extraction methods. Exchangeable concentrations $\left(\mathrm{Ca}^{\text {exch }}\right.$ and $\left.\mathrm{P}^{\text {exch }}\right)$ were extracted using $1 \mathrm{M}$ ammonium nitrate $\left(\mathrm{NH}_{4} \mathrm{NO}_{3}\right)$ extraction technique adapted from MAFF (1986). $0.5 \mathrm{~g}$ of soil was combined with $10 \mathrm{~mL} 1 \mathrm{M} \mathrm{NH}_{4} \mathrm{NO}_{3}$ in $30 \mathrm{~mL}$ polypropylene tubes and shaken for $33 \mathrm{~min}$ at $250 \mathrm{revs} \mathrm{min}^{-1}$, the reposed solution was then filtered (Whatman No. 42) and analysed on the ICP-OES. Total concentrations $\left(\mathrm{Ca}^{\mathrm{Tot}}\right)$ were extracted using nitric acid $\left(\mathrm{HNO}_{3}\right)$ digestion in a microwave (Anton Parr Multiwave 3000). $0.1 \mathrm{~g}$ of soil from each sample was digested with $6 \mathrm{~mL} 70 \% \mathrm{HNO}_{3}$ (Fisher Scientific Primar Plus Trace Metal grade) at $200{ }^{\circ} \mathrm{C} / 20$ Bar $(800 \mathrm{~W})$, for $30 \mathrm{mins}$. The microwaved solutions were then filtered (No. 42) and diluted (50 mL) with Ultra-pure $\mathrm{H}_{2} \mathrm{O}$. Quality Control was ensured through the analysis of process blanks and CRM samples (NWRI/INRE TH-2; extraction efficiency $C a=100.00 \%, R S D=3.98 ; P=87.18 \%$, $R S D=5.59$ ).

\section{Soil carbonate}

Calcium carbonate concentration was evaluated with a back titration (Cailleau et al. 2014). Briefly, $1 \mathrm{~g}$ of soil was combined with $0.25 \mathrm{M}$ Sulphuric acid $\left(\mathrm{H}_{2} \mathrm{SO}_{4}\right)$ and then back-titrated with $0.5 \mathrm{M} \mathrm{NaOH}$ until a $\mathrm{pH} 7$ was attained. It was not possible to confirm pure presence of $\mathrm{CaCO}_{3}$ using XRD and although a potential error induced by the presence of magnesium carbonate $\left(\mathrm{MaCO}_{3}\right)$ is small enough to preclude (Cailleau et al. 2005), $\mathrm{CaCO}_{3}$ concentrations are reported as $\left(\mathrm{Ca}_{1-\mathrm{x}}, \mathrm{Mg}\right.$ х) $\mathrm{CO}_{3} \%$ D.W..

Identification of oxalotrophy

Oxalotrophic bacterial analysis was completed on each study site, except Anse Rouge, utilising techniques adapted from Braissant et al. (2004). For each study site, $2 \mathrm{~g}$ of field moist sample was placed into a $50 \mathrm{~mL}$ centrifuge tube and vortexed for 1 min with $20 \mathrm{~mL}$ of $1 \%$ sodium hexametaphosphate $\left(\left[\mathrm{NaPO}_{3}\right]_{6}\right)$, before reposing for a further $20 \mathrm{mins}$ at room temperature. Serial dilutions $\left(10^{-2}\right.$ a $\left.10^{-4}\right)$ were made with $0.9 \%$ sodium chloride $(\mathrm{NaCl})$ solution and then propagated on petri dishes with two layers of media (Aragno and Schlegel 1992). The first layer was a Schegel medium ( $7 \mathrm{~g} \mathrm{~L}^{-1}$ ), while the second layer consisted of Schegel medium with $4 \mathrm{~g} \mathrm{~L}^{-1} \mathrm{CaOx}$ monohydrate $\left(\mathrm{CaC}_{2} \mathrm{O}_{4} \cdot \mathrm{H}_{2} \mathrm{O}\right)$, diluted to $10^{-2}$ or $10^{-4}$. Dishes were then incubated at $30{ }^{\circ} \mathrm{C}$ for $10-15$ days and counted for colonies, every $72 \mathrm{~h}$ after the 3 rd day of incubation.

Inverse modelling of a potential OCP

The quantity of $\mathrm{CO}_{2}{ }^{\mathrm{Atm}}$ captured during OCP bioinduced $\mathrm{CaCO}_{3}$ precipitation associated with an ideal oxalotrophic system was evaluated through the inverse modelling of observed variables and previous literature values (Benjamin et al. 2001; Cairns et al. 1997; Cairns 
et al. 2003; Gill and Jackson 2000; Peters 1989), using inverse modelling equations given in the Supplementary information. The model estimates a potential maximum biomineral $\mathrm{CaCO}_{3}$ precipitation and organic $\mathrm{C}$ sequestration associated with a $B$. alicastrum OCP by inverse modelling the biochemical characteristics ascertained with the aforementioned methods.

\section{Statistical analysis}

Statistical analysis was utilised to evaluate the potential oxalogenesis of B. alicastrum. All data was tested for homoscedasticity (Levene's test, $p>0.05$ ) and then analysed with partial correlation. Two-way ANOVAs or independent t-tests were applied using IBM SPSS Statistics Version 21, testing the differences between adjacent and control samples, in both countries.

\section{Results}

Calcium oxalate analysis

\section{Microscopy}

Optical microscopy revealed crystal deposits throughout B. alicastrum OM. Prismatic crystals were typically associated with the vascular structure of OM, while druse crystal deposits were associated with the lamina of B. alicastrum foliar tissue, from both Haiti and Mexico (Fig. 5). Crystals were present in all forms of sampled B. alicastrum tissue (leaf, branch, bark, and root), even in the youngest measured subjects $(<0.5 \mathrm{yrs})$, while in-situ SEM/EDS analyses detected $\mathrm{Ca}, \mathrm{C}$, and oxygen in the crystals. Their composition and crystallographic habiti (Verrecchia et al. 1993) confirmed their $\mathrm{CaOx}$ monohydrate nature (Fig. 5).

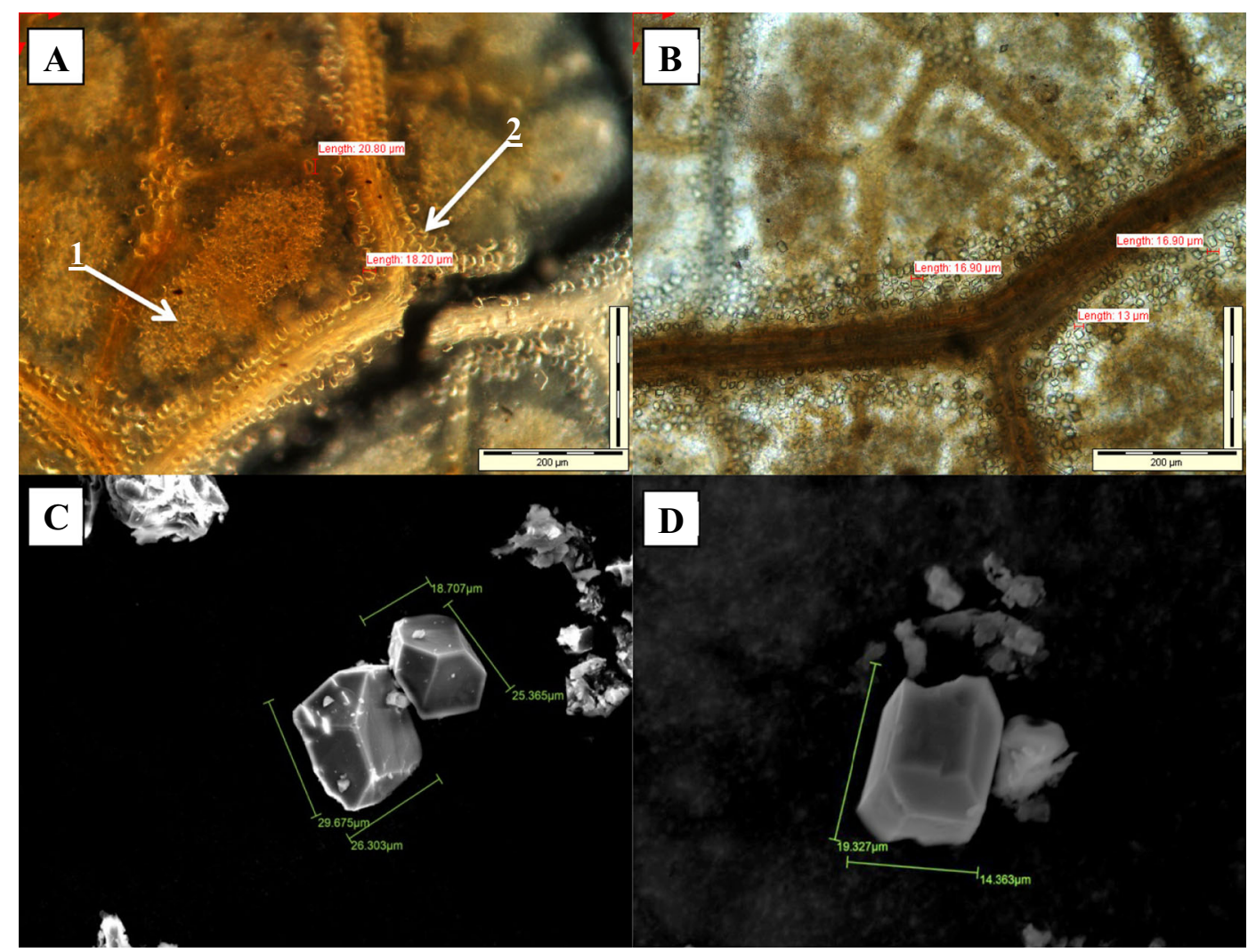

Fig. 5 Calcium oxalate crystals observed and imaged in Brosimum alicastrum tissue using optical and scanning electron microscopy. a Druse / sand CaOx crystals (1) associated with the lamina, and prismatic $\mathrm{CaOx}$ crystals (2) associated with the vascular system of foliar tissue from a Haitian subject. b Prismatic and druse $\mathrm{CaOx}$ crystals in foliar tissue from a Mexican subject. c Prismatic CaOx crystal isolated from the rhytidome of a Mexican subject. d Prismatic CaOx crystal isolated from a Mexican subject's root tissue all of which are prismatic habiti common in whewellite 


\section{Enzymatic oxalate analysis}

Enzymatic oxalate kit analyses quantified the presence of $\mathrm{CaOx}$ monohydrate in B. alicastrum tissue (Fig. 6). Highest concentrations of $\mathrm{CaOx}$ were discovered in Haitian leaf matter, while concentrations decreased with age, between the younger Haitian (mean $=97.26 \mathrm{~g} \mathrm{~kg}^{-1}$ ) and mature Mexican subjects (mean $=42.66 \mathrm{~g} \mathrm{~kg}^{-1}$, $\left.\mathrm{t}_{[19]}=4.385, p=0.001\right)$. High mean concentrations of $\mathrm{CaOx}$ were also found in B. alicastrum bark $(72.79 \mathrm{~g}$ $\mathrm{kg}^{-1}$ ) and root (57.86 $\mathrm{g} \mathrm{kg}^{-1}$ ) material from Mexico, with the lowest concentrations found in branch material of both countries $\left(\right.$ mean $\left.=38.30 \mathrm{~g} \mathrm{~kg}^{-1}\right)$. CaOx
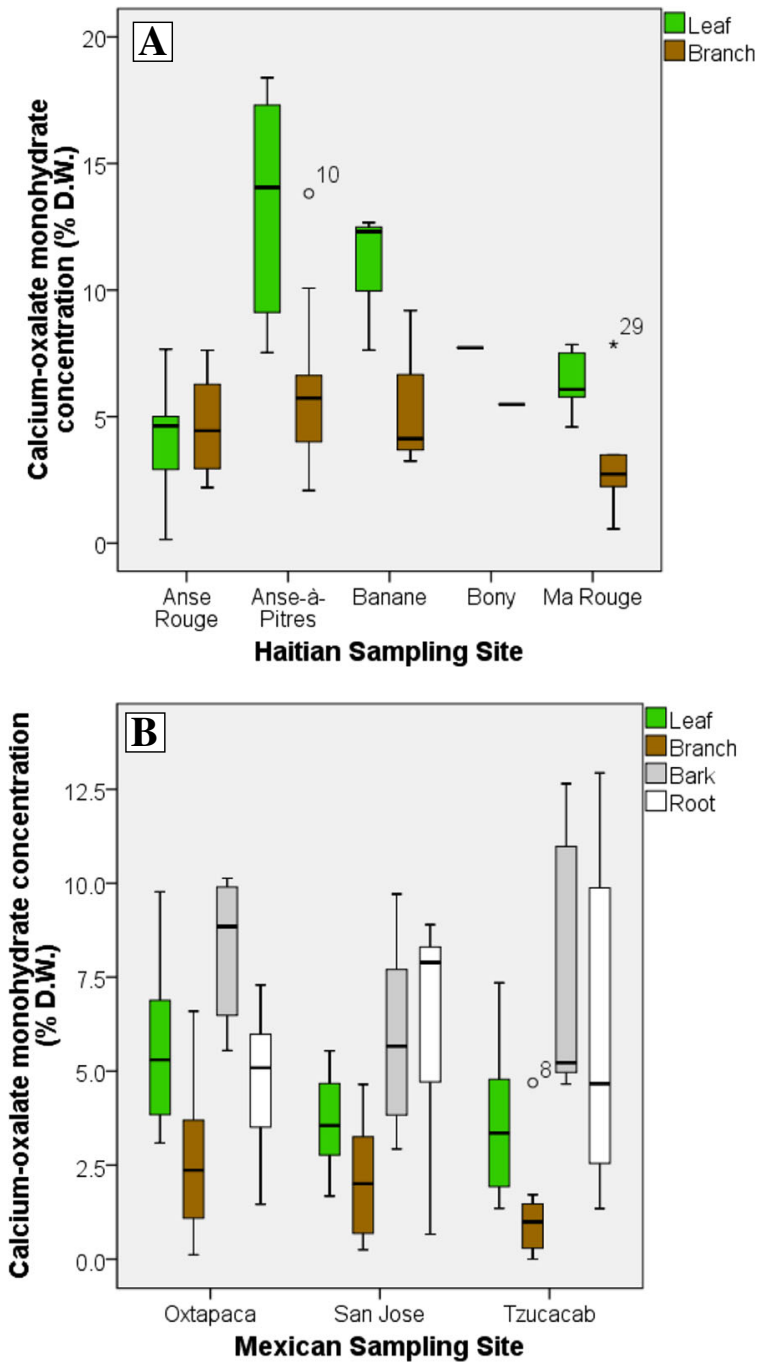

Fig. 6 Box plot graphs displaying oxalate concentrations (\% D.W.) of subject Brosimum alicastrum leaf and branch tissue at Haitian sampling sites (a), and leaf, bark, root and branch tissue at Mexican sampling sites (b) production did not correlate with $\mathrm{Ca}^{\text {Exch }}\left(r^{2}=0.208\right.$, $n=50)$ or $\mathrm{P}^{\mathrm{Exch}}\left(r^{2}=0.004, n=50\right)$.

Analysis of edaphic variables associated with the OCP

The effect of $B$. alicastrum on emblematic edaphic variables associated with the OCP was tested using two-way ANOVAs. The presence of B. alicastrum had a negligible effect on all edaphic variables related to the $\mathrm{OCP}$, at all sites combined $\left(\left[\mathrm{Ca}_{1-\mathrm{x}}, \mathrm{Mg} \mathrm{x}_{\mathrm{x}}\right] \mathrm{CO}_{3}\right.$ $\mathrm{F}_{[1,3]}=0.545, p=0.462, \mathrm{Ca}^{\mathrm{Tot}} \mathrm{F}_{[1,3]}=0.189, p=0.665$ $\& \mathrm{pH} \mathrm{F}[1,3]=0.07, p=0.787$ ), except Ma Rouge, Haiti. Ma Rouge displayed the lowest background concentrations of $\mathrm{Ca}^{\mathrm{Tot}}$ (mean $=6.74 \mathrm{~g} \mathrm{~kg}^{-1}$ ) and, although the subjects at Ma Rouge were very young ( $0.5-2$ yrs), the adjacent samples demonstrated clear germinal indications of oxalotrophy (Table 1), namely: (i) a distinct localised alkalinisation, (ii) an increase in concentrations of $\mathrm{Ca}^{\mathrm{Tot}}$, (iii; $\mathrm{Ca}_{1-\mathrm{x}}, \mathrm{Mg}_{\mathrm{x}}$ ) $\mathrm{CO}_{3}$ concentration (Fig. 7; Cailleau et al. 2014), and (iv) $\mathrm{P}^{\mathrm{Exch}}$, which is unrelated to the OCP, but can be an indicator of $\mathrm{CaOx}$ production and release, which subsequently liberates inorganic-bound $\mathrm{P}$ (Cannon et al. 1995). There was also an increase in $\mathrm{Ca}^{\text {Exch }}$ (mean increase $2.73 \mathrm{~g} \mathrm{~kg}^{-1}$ ) in the adjacent Ma Rouge sites, but not others $\left(\mathrm{F}_{[1,3]}=0.002, p=0.962\right)$, indicative of localised $\mathrm{Ca}$ cycling by the trees (Jobbágy and Jackson 2001).

Oxalotrophic microbial analysis

Oxalotrophy was detected in cultures from all sampling locations, in both Haiti and Mexico. All samples, except one experimental sample and four control Haitian samples, tested positive for oxalotroph colonies. Haitian study sites displayed a lower frequency of positive colonies than Mexican sites which could be due to the delay in customs; thus, making a direct comparison between the two impossible.

Sampling observations

Multiple mechanisms for the release of $B$. alicastrum produced $\mathrm{CaOx}$ were identified in association with subjects in both countries, for instance: phytophagous invertebrate predation (termite) and mycological decomposition (Fig. 8). Secondary carbonate deposits, confirmed through effervescence with $2 \mathrm{M} \mathrm{HCl}$, were found in association with the largest subjects in Mexico. These carbonate deposits were typically concentric, located mid-soil profile, in-between the root network of the subjects, and were 
Table 1 Independent samples t-tests comparing the means of edaphic variables related to the oxalate-carbonate pathway, in the adjacent and control profiles at the Ma Rouge sampling site

\begin{tabular}{|c|c|c|c|c|c|c|c|}
\hline \multirow[t]{2}{*}{ Variable } & \multicolumn{2}{|c|}{ Adjacent } & \multicolumn{2}{|c|}{ Control } & \multirow[t]{2}{*}{$\mathrm{t}$} & \multirow[t]{2}{*}{$\mathrm{P}$} & \multirow[t]{2}{*}{$\mathrm{Eta}^{2}$} \\
\hline & Mean & SD & Mean & SD & & & \\
\hline $\mathrm{pH}$ & 7.94 & 0.24 & 7.31 & 0.17 & 5.38 & 0.00 & 0.74 \\
\hline $\mathrm{Ca}^{\mathrm{Tot}}\left(\mathrm{g} \mathrm{kg}^{-1}\right)$ & 42.79 & 31.00 & 6.74 & 1.91 & 2.84 & 0.04 & 0.45 \\
\hline$\left(\mathrm{Ca}_{1-\mathrm{x}}, \mathrm{Mg}_{\mathrm{x}}\right) \mathrm{CO}_{3}$ (\% D.W. $)$ & 11.05 & 4.60 & 5.15 & 4.46 & 2.26 & 0.48 & 0.34 \\
\hline $\mathrm{P}^{\mathrm{Exch}} \times 10^{-3}\left(\mathrm{~g} \mathrm{~kg}^{-1}\right)$ & 8.09 & 3.37 & 1.63 & 1.40 & 4.34 & 0.00 & 0.65 \\
\hline
\end{tabular}

different in colour, texture and friability from the lithogenic carbonate, crumbling easily upon extraction (Fig. 8).

\section{Carbon capture potential}

The calculated values given in Tables 2 and 3 represent an ideal model of oxalotrophy, $\mathrm{CaOx}$ production, organic $\mathrm{C}$ sequestration, and also decomposition. Whereby, all $\mathrm{CaOx}$ and $\mathrm{C}$ captured by $B$. alicastrum as either organic $\mathrm{C}$ sequestration or $\mathrm{CaCO}_{3}$ precipitation, is stored within the associated $\mathrm{C}$ reserve. $\mathrm{CaOx}$ concentrations (\% D.W.) are calculated from the $\mathrm{CaOx}$ concentrations ascertained with the enzymatic oxalate analysis multiplied by the molecular weight of $\mathrm{CaOx}$ monohydrate (whewellite; $\mathrm{CaC}_{2} \mathrm{O}_{4} \cdot \mathrm{H}_{2} \mathrm{O}$ M.W.: $\left.142.112 \mathrm{~g} \mathrm{M}^{-1}\right)$, the most abundant form of $\mathrm{CaOx}$ in plants (Aragno et al. 2010).

\section{Discussion}

\section{Calcium oxalate and B. alicastrum}

The present study has demonstrated that $\mathrm{CaOx}$ is ubiquitous throughout all forms of analysed $B$. alicastrum tissues, and that production commences at a young age for the species $(<0.5 \mathrm{yrs})$. CaOx concentrations in subject tissue regularly exceeded $5 \%$ D.W. (Libert and Franceschi 1987) and the mean oxalate concentration for all sampled tissues in both Haiti and Mexico was $5.97 \%$ D.W. (59.71 $\mathrm{g} \mathrm{kg}^{-1}, n=140$ ). Furthermore, inverse modelling of the species' biochemical analysis revealed that $B$. alicastrum deposits significant quantities of $\mathrm{CaOx}$ into its surrounding edaphic ecosystem on an averaged, annual basis throughout its lifetime. The quantities of oxalate within its tissue are proportionally
Fig. 7 Box plot graphs displaying soil variables associated with the OCP from adjacent and control $(3.5 \mathrm{~m}$ distance) samples at Ma Rouge Haiti, which displayed the lowest background concentrations of total $\mathrm{Ca}$, in the following order: (a) soil $\mathrm{pH}$ values, (b) total calcium concentration and (c) calcium carbonate concentration, the purity of which was not ascertained
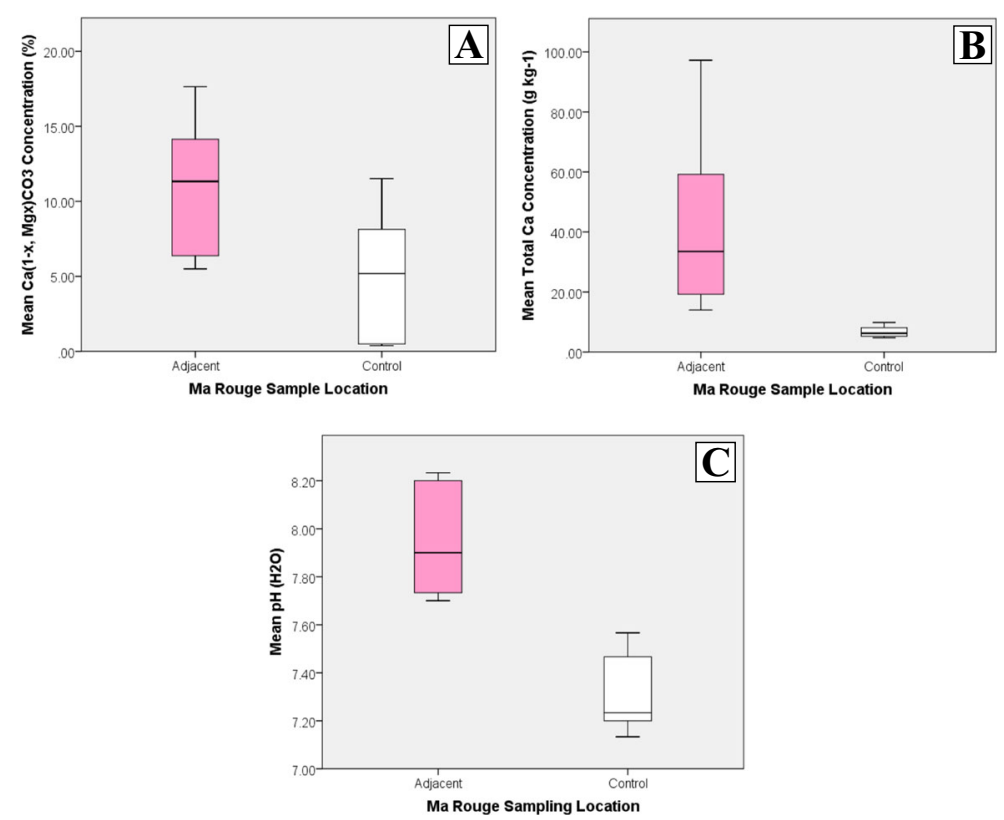
Fig. 8 Photographic observations from sampling. a Evidence of phytophagous invertebrate predation. b Mycological degradation of $\mathrm{CaOx}$ rich tissue in the rhizosphere adjacent to a Mexican subject. c Idiosyncratic carbonate mineral deposit, concentric and root-like in structure, located within the root network of a Mexican subject. d Concentric carbonate-rich mineral deposit at $1 \mathrm{~m}$ distance from a Mexican subject

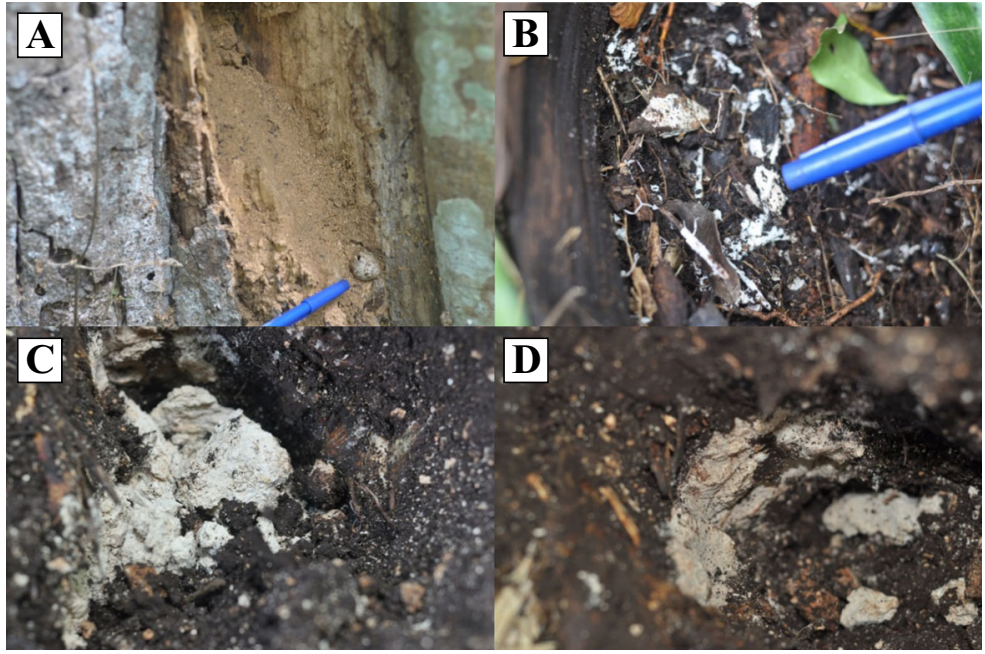

magnified by the species large biomass; thus, creating a potent source of potential OCP C storage if planted in an acidic soil environment free from a lithogenic carbonate source.

The primary phyto-function of $\mathrm{CaOx}$ production in $B$. alicastrum remains unclear. Contrary to previous studies, this investigation found no significant relationship between $B$. alicastrum's $\mathrm{CaOx}$ production and $\mathrm{Ca}^{\text {Exch }}$ (Austenfeld and Leder 1978; Rasmussen and Smith 1961; Volk et al. 2002) or $P^{\text {Exch }}$ (Cannon et al. 1995; Knight et al. 1992) concentrations in most sites, providing weak evidence that $\mathrm{CaOx}$ production is utilised for the phyto-regulation of $\mathrm{Ca}^{\mathrm{Exch}}$ or release of $\mathrm{P}^{\mathrm{Exch}}$ from inorganic-pools. Equally, the use of $B$. alicastrum tissue for fodder and the non-raphide morphology or size of crystals (Sakai et al. 1984; Salinas et al. 2001) indicate that the

Table 2 Mean calcium oxalate and carbon contents of $B$. alicastrum tissue from both countries used in the inverse modelling of the carbon capture ability of an ideal individual or hectare population

\begin{tabular}{lll}
\hline Tissue type & $\begin{array}{l}\text { Mean calcium } \\
\text { oxalate content } \\
(\% \text { D.W. })\end{array}$ & $\begin{array}{l}\text { Mean total } \\
\text { carbon }(\% \text { D.W. })\end{array}$ \\
\hline Leaf & 7.54 & 35.68 \\
Branch & 3.91 & 41.63 \\
Bark & 7.28 & 45.70 \\
Root & 5.79 & 41.34 \\
Mean tissue & 5.97 & 39.98 \\
\hline
\end{tabular}

species does not use $\mathrm{CaOx}$ production as an herbivory deterrent. However, the concentrated production of druse crystals in the lamina of $B$. alicastrum foliar tissue could distribute UV light to chloroplasts, increasing incident UV absorbency in understory environments, as originally hypothesised by Franceschi (2001) and later demonstrated experimentally by Kuo-Huang et al. (2007) in Peperomia glabella. This hypothesis explains the observed decrease in subject foliar $\mathrm{CaOx}$ concentration with age, while also explaining $B$. alicastrum's high survival rates under dense canopy ( $>80 \%$; Laborde and Corrales-Ferrayola 2012). Therefore, a role for B. alicastrum $\mathrm{CaOx}$ druse crystal production in the maximisation of incident UV light is hypothesised.

During this investigation, the root network of B. alicastrum was of particular interest. B. alicsatrum has a root network that is mainly concentrated in the upper soil and bedrock layers (Querejeta et al. 2006). The EOK analyses indicated that $B$. alicastrum root tissue contains a significant concentration of $\mathrm{CaOx}$, which, when coupled with the Cairns et al. (1997) root / shoot ratio (0.26) and Gill and Jackson (2000) root turnover rate $\left(0.1 \mathrm{yr}^{-1}\right)$, predict that $B$. alicastrum deposits significant quantities of $\mathrm{CaOx}$ directly into its rhizosphere through the continuous decomposition and regeneration of root OM. Furthermore, investigations have demonstrated that B. alicastrum roots have strong associations with mycorrhizal fungi (Allen et al. 2003; Allen et al. 2005) that, Bravo et al. (2013) demonstrated act as highways for the dispersal of oxalotrophic bacteria to oxalate, creating an ideal mutualistic habitat for oxalotrophy. 
Table 3 Estimates for the carbon capture ability of an ideal B. alicastrum individual and hectare plantation of 400 individuals

\begin{tabular}{|c|c|c|c|c|c|}
\hline Predictions & $\begin{array}{l}\text { Total calcium } \\
\text { oxalate } \\
\text { output }(\mathrm{kg})\end{array}$ & $\begin{array}{l}\text { Potential biomineral } \\
\text { precipitation of captured } \\
\mathrm{CO}_{2}{ }^{\mathrm{ATM}} \text { as } \mathrm{CaCO}_{3}(\mathrm{~kg})\end{array}$ & $\begin{array}{l}\text { Potential organic carbon } \\
\text { sequestration of } \mathrm{CO}_{2}{ }^{\mathrm{Atm}} \\
\text { as biomass }(\mathrm{kg})\end{array}$ & $\begin{array}{l}\text { Potential } \\
\text { total } \mathrm{CO}_{2} \\
\text { capture }(\mathrm{kg})\end{array}$ & $\begin{array}{l}\text { Annual } \mathrm{CO}_{2} \\
\text { capture }\left(\mathrm{kg} \mathrm{yr}^{-1}\right. \\
\left.\mathrm{MLE}^{-1}\right)\end{array}$ \\
\hline Individual & 1590 & 479 & 39,633 & 40,112 & 267 \\
\hline 1 ha plantation (400 individuals) & 636,000 & 191,600 & $15,853,200$ & $16,048,800$ & 106,800 \\
\hline
\end{tabular}

OCP and carbonate soils

All the constituents of an active OCP in ferralitic soils have now been identified by this investigation in calcareous ecosystems adjacent to B. alicastrum in both Haiti and Mexico. These constituents include: an oxalate producing species ( $B$. alica strum), phytophagous invertebrate predation and mycological decomposition of $\mathrm{CaOx}$ rich tissue, significant oxalotrophic bacterial communities, and secondary $\mathrm{CaCO}_{3}$. Furthermore a calcareous sample site in Haiti, Ma Rouge, has demonstrated clear, emblematic, early indications of oxalotrophy adjacent to subjects (Table 2) even though the subjects are still very young $(0.5-2 \mathrm{yrs})$. This was contrary to our hypothesis that the trees would be too young to have affected their local edaphic ecosystem; but, at the time of sampling, the Ma Rouge trees had already grown to $1.4-1.8 \mathrm{~m}$ in height and were producing significant quantities of $\mathrm{CaOx}$, which was also detectable in the soils adjacent to them (5$25 \mathrm{~g} \mathrm{~kg}^{-1}$ ). As demonstrated by Bravo et al. (2011), this soil $\mathrm{CaOx}$ pool can be catabolised quickly upon entry into the edaphic ecosystem when in the presence of oxalotrophs. Which, when coupled with positive identification of oxalotrophy in soils found adjacent to B. alicastrum in $\mathrm{Ma}$ Rouge, strongly suggests that, like suggested by Verrecchia et al. (1993), an OCP can occur in calcareous environments and secondary carbonate deposits found in association with the root networks in Mexico are generated through an active OCP.

Although there was evidence of oxalotrophy in $\mathrm{Ma}$ Rouge, typical edaphic variables associated with the OCP were suppressed in most sites. This could be because of the higher concentrations of $\mathrm{Ca}\left(\mathrm{Ca}^{\text {Exch }} \& \mathrm{Ca}^{\mathrm{Tot}}\right)$ masking the typical indicators of an OCP. Ma Rouge displayed the lowest concentrations of $\mathrm{Ca}\left(\mathrm{Ca}^{\text {Exch }} \& \mathrm{Ca}^{\text {Tot }}\right)$ or $\mathrm{CaCO}_{3}$
( 2 sites below the calcaric threshold) of any site samples. The site was also the only site to present evidence of $\mathrm{Ca}^{\text {Exch }}$ cycling by the plants (Jobbágy and Jackson 2001). However, the passive cycling of $\mathrm{Ca}$ could not explain the observed increase in $\mathrm{CaCO}_{3}$ content of adjacent samples. On the contrary, there was a larger increase in adjacent concentrations of $\mathrm{Ca}^{\text {Tot }}$, relative to $\mathrm{Ca}^{\text {Exch }}$, which, as a plant nutrient would be actively cycled by plants. This increase is most likely linked to the $\mathrm{CaCO}_{3}$ increase adjacent to the species, as will be the localised alkalinisation. A significant saturation of exchange complex by $\mathrm{Ca}\left(>4.47 \mathrm{~g} \mathrm{~kg}^{-1}\right)$ of a deprotonated alkaline soil would typically suppress the localised alkalinisation associated with an OCP in ferralitic environments; but, the observed increase in $\mathrm{CaCO}_{3}$ would further increase $\mathrm{pH}$ as seen in Ma Rouge. Although the presence of lithogenic $\mathrm{CaCO}_{3}$ makes it difficult to discern secondary $\mathrm{CaCO}_{3}$ deposits and thereby, identify an active OCP (Cailleau et al. 2014), the root-like position, colour, shape, texture and friability of secondary $\mathrm{CaCO}_{3}$ deposits in Mexico were all suggestive of an OCP associated with B. alicastrum. Therefore, $\mathrm{Ca}$ and $\mathrm{C}$ cycling of the $\mathrm{OCP}$ in calcareous environments needs to be studied in more detail to identify alternate indicators of the process in alkaline soils.

In calcareous environments, plants under stress from high $\mathrm{Ca}^{\text {Exch }}$ concentrations, typically increase $\mathrm{CaOx}$ production as a $\mathrm{Ca}$ detoxification mechanism (Austenfeld and Leder 1978; Molano-Flores 2001; Rasmussen and Smith 1961; Volk et al. 2002; Webb 1999). This increased production of $\mathrm{CaOx}$ would theoretically lead to a larger pool available for oxalotrophy relative to a ferralitic environment, subsequently increasing the $\mathrm{C}$ cycling of the process. However, an identifiable $\mathrm{C}$ sequestration of a calcareous OCP must be ruled out because $\mathrm{CO}_{2}$ is concomitantly released into the soil matrix when $\mathrm{Ca}^{2+}$ is liberated during the 


\section{$2 \mathrm{H}^{+}+\mathrm{CaCO}_{3} \Leftrightarrow \mathrm{Ca}^{2+}+\mathrm{CO}_{2}+\mathrm{H}_{2} \mathrm{O}$}

Fig. 9 The acidic dissolution of limestone frees $\mathrm{Ca}$ in the soil solution for the OCP, but also degases carbon dioxide. This supposes the presence of strong acids. However, for the details of the general balance of the OCP involving calcium carbonate, calcium oxalate, and $\mathrm{CO}_{2}$, please see Verrecchia et al. (2006)

dissolution of $\mathrm{CaCO}_{3}$ in calcareous environments (Fig. 9). This means that a calcareous OCP system cannot truly be considered a $\mathrm{C}$ sink, but instead a $\mathrm{C}$ capturer, as the allochthonous, non-carbonate origin of the $\mathrm{Ca}^{2+}$ precipitated as $\mathrm{CaCO}_{3}$ cannot be confirmed in this complex system. Instead, this work has confirmed that $B$. alicastrum is an oxalogenic species which is known to have significant agroforestry potential (Woda and Martinez 2013) and if planted in a location free from lithogenic $\mathrm{CaCO}_{3}$, would act as an efficient agroforestry and $\mathrm{C}$ capture tool.

\section{Conclusion}

Calcium oxalate production takes place throughout $B$. alicastrum tissue and the compound likely plays an important role in the species' adolescent form, maximising photosynthesis, through the augmentation of incident UV radiation in the lamina, in lightlimited environments. This research has also identified oxalotrophic bacterial communities in soils from Haiti and Mexico, providing further evidence for previous suggestions that oxalotrophism is globally diverse. Furthermore, this study has provided experimental evidence for the hypothesis of Verrecchia et al. (1993) that, the OCP can occur in calcareous environments. Thus, when planted in soils free from lithogenic carbonate, B. alicastrum would represent a valuable $\mathrm{C}$ sequestration and agroforestry crop which would have the ability to biominerally sequester $\mathrm{C}$ via an active $\mathrm{OCP}$, while providing food for Neotropical communities in countries such as Haiti, Mexico or Belize. Further investigation is now required to:

1. Analyse $B$. alicastrum in acidic soil environments,

2. Assess the isotopic signatures of discovered carbonate deposits,

3. Assess the origin of $\mathrm{Ca}$ sources in calcareous OCP systems,
4. Identify more oxalogenic species with significant agroforestry potential, to facilitate integration of this biogeochemical $\mathrm{C}$ management solution into current agroforestry systems.

Acknowledgments The authors would like to acknowledge and thank the entire Sadhana Forest organisation, not only for their financial contribution, but also their continued council, volunteering and friendly support throughout this research. We would like to thank Dr. David Sebag for his excellent internal review and improvements to our draft manuscript. The authors would also like to acknowledge Chris R., Bournemouth University, and Daniel Rodary of Biomimicry Europa for financial contributions towards the research. Thanks furthermore to Oscar Alvárez Rivera, Beatriz Aguilar Silveira, : Pete Armstrong for his much appreciated graphical support, FERA - license number: 111808/ 198476/3, Artik 29 \& Hebert, Erika Vohman of the The Maya Nut Institute, Adolfo of Colatinco, Paola Barbuto, Lydia Maschin, Carlyle Collins, Erica, Chris \& Heather.

Open Access This article is distributed under the terms of the Creative Commons Attribution 4.0 International License (http:// creativecommons.org/licenses/by/4.0/), which permits unrestricted use, distribution, and reproduction in any medium, provided you give appropriate credit to the original author(s) and the source, provide a link to the Creative Commons license, and indicate if changes were made.

\section{References}

Allen EB, Allen ME, Egerton-Warburton L, Corkidi L, GomezPompa A (2003) Impacts of early- and late-seral mycorrhizae during restoration in seasonal tropical forest, Mexico. Ecol Appl 13:1701-1717. doi:10.1890/02-5309

Allen MF, Allen EB, Gomez-Pompa A (2005) Effects of mycorrhizae and nontarget organisms on restoration of a seasonal tropical forest in Quintana Roo, Mexico: Factors limiting tree establishment. Restor Ecol 13:325-333. doi:10.1111/j.1526100X.2005.00041.x

Aragno M, Schlegel HG (1992) The mesophilic hydrogenoxidizing (Knallgas) bacteria. In: Balows A, Trüper HG, Dworkin M, Harder W, Schleifer H (eds) The prokaryotes, 2nd edn. Springer, Berlin

Aragno A, Verrecchia EP, Job D, Cailleau G, Braissant O, Khammar N, Ferro K, Mota M, Guggiari M, Martin G (2010) Calcium carbonate biomineralization in ferralitic, tropical soils through the oxalate-carbonate pathway. BGS Bull 30:127-130

Austenfeld F-A, Leder U (1978) Über den Oxalathaushalt von Salicornia europaea L. unter dem Einfluß variierter Erdalkalisalz-Gaben. Zeitschr für Pflanzenphysiol 88:403412. doi:10.1016/S0044-328X(78)80256-6

Barry KM, Pinkard EA (2013) Growth and photosynthetic responses following defoliation and bud removal in eucalypts. 
For Ecol Manage 293:9-16. doi:10.1016/j. foreco.2012.12.012

Bassalik K (1913) Ueber die Verarbeitung der Oxalsäure durch Bacillus extorquens. Jahrbüch für Wissenschaft Botan 53: 255-302

Benjamin TJ, Montañez PI, Jaménez JJM, Gillespie AR (2001) Carbon, water and nutrient flux in Maya homegardens in the Yucatán peninsula of México. Agroforest Syst 53:103-111. doi:10.1023/a:1013312217471

Braissant O, Verrecchia EP, Aragno M (2002) Is the contribution of bacteria to terrestrial carbon budget greatly underestimated? Naturwissenschaften 89:366-370. doi:10.1007/s00114-002-0340-0

Braissant O, Cailleau G, Aragno M, Verrecchia EP (2004) Biologically induced mineralization in the tree Milicia excelsa (Moraceae): its causes and consequences to the environment. Geobiology 2:59-66. doi:10.1111/j.14724677.2004.00019.x

Bravo D, Braissant O, Solokhina A, Clerc M, Daniels AU, Verrecchia E, Junier P (2011) Use of an isothermal microcalorimetry assay to characterize microbial oxalotrophic activity. Fems Microbiol Ecol 78:266-274. doi:10.1111/j.15746941.2011.01158.x

Bravo D, Cailleau G, Bindschedler S, Simon A, Job D, Verrecchia E, Junier P (2013) Isolation of oxalotrophic bacteria able to disperse on fungal mycelium. Fems Microbiol Lett 348:157166. doi:10.1111/1574-6968.12287

Brewer SW, Rejmanek M, Webb MAH, Fine PVA (2003) Relationships of phytogeography and diversity of tropical tree species with limestone topography in southern Belize. $\mathrm{J}$ Biogeogr 30:1669-1688. doi:10.1046/j.13652699.2003.00971.x

Cailleau G, Braissant O, Verrecchia EP (2004) Biomineralization in plants as a long-term carbon sink. Naturwissenschaften 91: 191-194. doi:10.1007/s00114-004-0512-1

Cailleau G, Braissant O, Dupraz C, Aragno M, Verrecchia EP (2005) Biologically induced accumulations of $\mathrm{CaCO} 3$ in orthox soils of Biga, Ivory Coast. Catena 59:1-17. doi:10.1016/j.catena.2004.06.002

Cailleau G, Braissant O, Verrecchia EP (2011) Turning sunlight into stone: the oxalate-carbonate pathway in a tropical tree ecosystem. Biogeosciences 8:1755-1767. doi:10.5194/bg-81755-2011

Cailleau G, Mota M, Bindschedler S, Junier P, Verrecchia EP (2014) Detection of active oxalate-carbonate pathway ecosystems in the Amazon Basin: global implications of a natural potential C sink. Catena 116:132-141. doi:10.1016/j. catena.2013.12.017

Cairns MA, Brown S, Helmer EH, Baumgardner GA (1997) Root biomass allocation in the world's upland forests. Oecologia 111:1-11. doi:10.1007/s004420050201

Cairns MA, Olmsted I, Granados J, Argaez J (2003) Composition and aboveground tree biomass of a dry semi-evergreen forest on Mexico's Yucatan Peninsula. For Ecol Manage 186:125132. doi:10.1016/s0378-1127(03)00229-9

Cannon JP, Allen EB, Allen MF, Dudley LM, Jurinak JJ (1995) The effects of oxalates produced by salsola-tragus on the phosphorus-nutrition of stipa-pulchra. Oecologia 102:265272. doi:10.1007/bf00329792

Certini G, Corti G, Ugolini FC (2000) Vertical trends of oxalate concentration in two soils under Abies alba from
Tuscany (Italy). J Plant Nutr Soil Sci 163:173-177. doi:10.1002/(sici)1522-2624(200004)163:2<173::aidjpln173>3.0.co;2-h

Chandra TS, Shethna YI (1977) Oxalate, formate, formamide, and methanol metabolism in Thiobacillus novellus. J Bacteriol 131:389-398

Cromack K, Sollins P, Todd RL, Fogel R, Todd AW, Fender WM, Crossley ME, Crossley DA (1977) The role of oxalic acid and bicarbonate in calcium cycling by fungi and bacteria: some possible implications for soil animals. Ecol Bull 25: 246-252. http://www.jstor.org/stable/20112586

Esri (2014) Basemap, sources: National Geographic, Esri, DeLorme, HERE, UNEP-WCMC, USGS, NASA, ESA< METI, NRCRAn, GEBCO, NOAA, iPC

Faheed F, Mazen A, Abd Elmohsen S (2013) Physiological and ultrastructural studies on calcium oxalate crystal formation in some plants. Turk J Botan 37:139-152. doi:10.3906/bot1112-19

Ferro KI (2012) The impact of oxalogenic plants on soil carbon dynamics - formation of a millennium storage as calcium carbonate. Université de Neuchâtel, Neuchâtel

Franceschi V (2001) Calcium oxalate in plants. Trends Plant Sci 6: 331. doi:10.1016/S1360-1385(01)02014-3

Franceschi VR, Nakata PA (2005) Calcium oxalate in plants: formation and function. Annu Rev Plant Biol 56:41-71. doi:10.1146/annurev.arplant.56.032604.144106

Garvie LAJ (2003) Decay-induced biomineralization of the saguaro cactus (Carnegiea gigantea). Am Mineral 88: 1879-1888

Garvie LAJ (2006) Decay of cacti and carbon cycling. Naturwissenschaften 93:114-118. doi:10.1007/s00114-0050069-7

Giddings L, Soto M (2003) Rhythms of precipitation in the Yucatán Peninsula. In: Gomez-Pompa A, Allen MF, Fedick SL, Jiménez-Osornio JJ (eds) The lowland maya area: three millennia at the human-wildland influence. Food Products Press, Oxford

Gill RA, Jackson RB (2000) Global patterns of root turnover for terrestrial ecosystems. New Phytol 147:13-31. doi:10.1046 j.1469-8137.2000.00681.x

Gillespie AR, Bocanegra-Ferguson DM, Jimenez-Osornio JJ (2004) The propagation of Ramon (Brosimum alicastrum Sw.; Moraceae) in Mayan homegardens of the Yucatan peninsula of Mexico. New Forest 27:25-38. doi:10.1023 /a:1025081224852

Harder W, Wiersma M, Groen L (1974) Transport of substrates and energetics of growth of Pseudomonas oxalaticus during growth on formate or oxalate in continous culture. J Gen Microbiol 81:R2-R3

Ilarslan H, Palmer RG, Horner HT (2001) Calcium oxalate crystals in developing seeds of soybean. Ann Bot 88:243-257. doi:10.1006/anbo.2001.1453

Jayasuriya GCN (1955) The isolation and characterisitics of an oxalate-decomposing organism. J Gen Microbiol 12:419 428

Jobbágy EG, Jackson RB (2001) The distribution of soil nutrients with depth: global patterns and the imprint of plants. Biogeochem 53:51-77. doi:10.1023 /a:1010760720215 
Knight WG, Dudley LM, Jurinak JJ (1992) Oxalate effects on solution phosphorus in a calcareous soil. Arid Soil Res Rehab 6:11-20

Kuo-Huang LL, Maurice SBK, Franceschi VR (2007) Correlations between calcium oxalate crystals and photosynthetic activities in palisade cells of shade-adapted Peperomia glabella. Botan Stud 48:155-164

Laborde J, Corrales-Ferrayola I (2012) Direct seeding of Brosimum alicastrum Sw. (Moraceae) and Enterolobium cyclocarpum (Jacq.) Griseb. (Mimosaceae) in different habitats in the dry tropics of central Veracruz. Acta Botanica Mexican 100:107-134

Libert B, Franceschi VR (1987) Oxalate in crop plants. J Agric Food Chem 35:926-938. doi:10.1021/jf00078 a019

MAFF (1986) The analysis of agricultural materials: a manual of the analytical methods used by the agricultural development and advisory service, 2nd ed. Her Majesty's Stationery Office, London

Martin G, Guggiari M, Bravo D, Zopfi J, Cailleau G, Aragno M, Job D, Verrecchia E, Junier P (2012) Fungi, bacteria and soil $\mathrm{pH}$ : the oxalate-carbonate pathway as a model for metabolic interaction. Environ Microbiol 14:2960-2970. doi:10.1111 /j.1462-2920.2012.02862.x

Molano-Flores B (2001) Herbivory and calcium concentrations affect calcium oxalate crystal formation in leaves of Sida (Malvaceae). Ann Bot 88:387-391. doi:10.1006 /anbo.2001.1492

Monje PV, Baran EJ (2002) Characterization of calcium oxalates generated as biominerals in cacti. Plant Physiol 128:707713. doi: $10.1104 / \mathrm{pp} .010630$

Nakata PA (2002) Calcium oxalate crystal morphology. Trends Plant Sci 7:324-324. doi:10.1016/s1360-1385 (02)02285-9

Nakata PA (2003) Advances in our understanding of calcium oxalate crystal formation and function in plants. Plant Sci 164:901-909. doi:10.1016/s0168-9452(03)00120-1

Ortiz M, Azanón Y, Melgar M, Elias L (1995) The corn tree (Brosimum alicastrum): a food for the tropics. In: Simopoulos AP (ed) Plants in human nutrition, world review of nutrition and diabetics. Kargel Publishers, Basel

Palak VR, Harisha CR, Prakapati PK (2012) Importance of calcium oxalate crystals in panchavalkala. Int $\mathrm{J}$ Pharmacog Phytochem Res 4:112-116

Peters CM (1983) Observations on Maya subsistence and the ecology of a tropical tree. Amer Antiq 48:610-615. doi: $10.2307 / 280569$

Peters CM (1989) Reproduction, growth and the population dynamics of Brosimum alicastrum Sw. in a moist tropical forest of Central Veracruz, Mexico.

Peters CM, Pardo-tejeda E (1982) Brosimum-alicastrum (Moraceae) - uses and potential in Mexico. Econom Botan 36:166-175. doi:10.1007/bf02858712

Querejeta JI, Estrada-Medina H, Allen MF, Jimenez-Osornio JJ, Ruenes R (2006) Utilization of bedrock water by Brosimum alicastrum trees growing on shallow soil atop limestone in a dry tropical climate. Plant and Soil 287:187-197. doi:10.1007/s11104-006-9065-8

Ramos EL (1975) Geological summary of the Yucatan Peninsula. In: Nairn AEM, Stehli FG (eds) The Gulf of Mexico and the Caribbean. Springer US, Boston
Rasmussen G, Smith PF (1961) Effects of calcium, potassium, and magnesium on oxalic, malic, and citric acid content of Valencia orange leaf tissue. Plant Physiol 36:99-. doi:10.1104/pp.36.1.99

Rico-gray V, Chemas A, Mandujano S (1991) Uses of tropical deciduous forest species by the Yucatecan Maya. Agroforest Syst 14:149-161. doi:10.1007/bf00045730

Sahin N (2003) Oxalotrophic bacteria. Res Microbiol 154:399 407. doi:10.1016/s0923-2508(03)00112-8

Sakai WS, Shiroma SS, Nagao MA (1984) A study of raphide microstructure in relation to irritation. Scan Electron Microscop II(Pt 2):979-986

Salinas ML, Ogura T, Soffchi L (2001) Irritant contact dermatitis caused by needle-like calcium oxalate crystals, raphides in Agave tequilana among workers in tequila distilleries and agave plantations. Contact Dermatitis 44:94-96. doi:10.1034 j.1600-0536.2001.440208.x

Scholz G, Liebner F, Koch G, Bues C-T, Guenther B, Baeucker E (2007) Chemical, anatomical and technological properties of Snakewood Brosimum guianense (Aubl.) Huber. Wood Sci Technol 41:673-686. doi:10.1007/s00226-007-0149-2

Schutz AEN, Bond WJ, Cramer MD (2009) Juggling carbon: allocation patterns of a dominant tree in a fireprone savanna. Oecologia 160:235. doi:10.1007 /s00442-009-1293-1

Shang C, Tiessen H (2003) Soil organic C sequestration and stabilization in karstic soils of Yucatan. Biogeochem 62: 177-196. doi:10.1023/a:1021123728639

Tamer AÜ, Aragno M (1980) Isolement, characterisation et essai d'identifcation de bactéries capables d'utiliser l'oxalate comme seule source de carbone et d'énergie. Bull Soc Neuchâtel Sci Nature 103:91-104

Verrecchia EP (1990) Litho-diagenetic implications of the calcium oxalate-carbonate biogeochemical cycle in semiarid Calcretes, Nazareth, Israel. Geomicrobiol J 8:87-99. doi:10.1080/01490459009377882

Verrecchia EP, Dumont J-L, Verrecchia KE (1993) Role of calcium oxalate biomineralization by fungi in the formation of calcretes; a case study from Nazareth, Israel. J Sediment Res 63:1000-1006. doi:10.1306/d4267c6c-2b26-11d7$8648000102 \mathrm{c} 1865 \mathrm{~d}$

Verrecchia EP, Braissant O, Cailleau G (2006) The oxalate-carbonate pathway in soil carbon storage: the role of fungi and oxalotrophic bacteria. Cambridge University Press

Volk GM, Lynch-Holm VJ, Kostman TA, Goss LJ, Franceschi VR (2002) The role of druse and raphide calcium oxalate crystals in tissue calcium regulation in Pistia stratiotes leaves. Plant Biol 4:34-45. doi:10.1055/s-2002-20434

Webb MA (1999) Cell-mediated crystallization of calcium oxalate in plants. Plant Cell 11:751-761

Whigham DF, Lynch JF (1998) Responses of plants and birds to hurricane disturbances in a dry tropical forest of Quintana Roo, Mexico. In: Dallmeier F, Comiskey JA (eds) Forest biodiversity in North, Central and South America, and the Caribbean. The Parthenon Publishing Group, Paris

Whigham DF, Olmsted I, Cabrera Cano E, Curtis AB (2003) Impacts of hurricanes on the forests of Quintana Roo, Yucatán Peninsula, Mexico. In: Gomez-Pompa A, Allen MF, Fedick SL, Jiménez-Osornio JJ (eds) The lowland 
Maya area: three millennia at the human-wildland influence. Food Products Press, Oxford

Woda C, Martinez M (2013) Nueces de Masica (Brosimum alicastrum) como alimento humano - el potencial de producción de un bosque tropical húmedo en Honduras. Sistema de Investigación Nacional Forestal, Áreas Protegidas y Vida Silvestre - SINFOR El VIII Congresso Forestal Centroamericano, San Pedro Sula, Honduras

WRB W-IWG (2015) World reference base for soil resources 2014, update 2015. In: WS Resources (ed) No 106. FAO, Rome
Wright AF, Bailey JS (2001) Organic carbon, total carbon, and total nitrogen determinations in soils of variable calcium carbonate contents using a Leco CN-2000 dry combustion analyzer. Commun Soil Sci Plant Anal 32:3243-3258. doi:10.1081/css-120001118

Wu CC, Kuo Huang LL (1997) Calcium crystals in the leaves of some species of Moraceae. Botan Bull Acad Sin 38:97-104

Yates S, Ramirez-Sosa CR (2004) Ethnobotanical knowledge of Brosimum alicastrum (Moraceae) among urban and rural El Salvadorian adolescents. Econom Botan 58:72-77. doi:10.1663/0013-0001(2004)058[0072:ekobam]2.0.co;2 